\title{
Anal Hemorrhage
}

National Cancer Institute

\section{Source}

National Cancer Institute. Anal Hemorrhage. NCI Thesaurus. Code C78168.

Bleeding originating from the anal area. 